of the amount of the annual subscription. This varies with the price of $2 \frac{1}{2}$ per cent Consols and the basis is a very stringent one, since the amounts payable are those required if fellows had entered into agreements to continue their annual subscriptions for the remainder of their lives.

The most elaborate scale is that of the Geological Society of London. The full table contains some thousands of entries; it quotes the commutation fee for each age at election from twenty to eighty, combined with each number of annual contributions already paid, from nought to fifty. It does not seem to have been noticed that, in general, age at election plus number of annual contributions already paid equals present age. Apart from a few unnecessary irregularities, the vast table could be replaced by its top line with "age last birthday" substituted for "age at election" or by its first column.

The commutation scales of these societies for ages forty to seventy, all expressed as per $£ 1$ of annual subscription, are summarized in the accompanying table and graph, which also give suggested maximum and minimum scales. The maximum scale, which on the graph can scarcely be shown separately from that of the Royal Society, is based on the Mortality of Annuitants, 1900-1920, $a(m) 3 \%$ Ultimate.

COMMUTATHON FURS PMR £L OF ANNUAL SUBSCRIPTION

\begin{tabular}{|c|c|c|c|c|c|c|c|}
\hline & \multicolumn{7}{|c|}{ Age last birthday } \\
\hline & 40 & 45 & 50 & 55 & 60 & 65 & 70 \\
\hline $\begin{array}{l}\text { Institute of } \\
\text { Actuaries }\end{array}$ & - & $10 \cdot 0$ & $8 \cdot 3$ & $6 \cdot 7$ & $5 \cdot 0$ & $2 \cdot 5$ & Nil \\
\hline $\begin{array}{l}\text { Royal Society* } \\
\text { Geological }\end{array}$ & $19 \cdot 8$ & $18 \cdot 2$ & $16 \cdot 4$ & $14 \cdot 4$ & $12 \cdot 4$ & $10 \cdot 4$ & $8 \cdot 5$ \\
\hline Society & $14 \cdot 3$ & $13 \cdot 5$ & $12 \cdot 7$ & $11 \cdot 1$ & $9 \cdot 5$ & $6 \cdot 3$ & $4 \cdot 8$ \\
\hline Suggested & $20 \cdot 1$ & 18.4 & $16 \cdot 7$ & $14 \cdot 8$ & $12 \cdot 9$ & $10 \cdot 9$ & $9 \cdot 1$ \\
\hline Suggested & & & & & & & \\
\hline minima & $10 \cdot 0$ & $9 \cdot 2$ & $8 \cdot 3$ & $7 \cdot 4$ & $6 \cdot 4$ & $5 \cdot 5$ & $4 \cdot 5$ \\
\hline
\end{tabular}

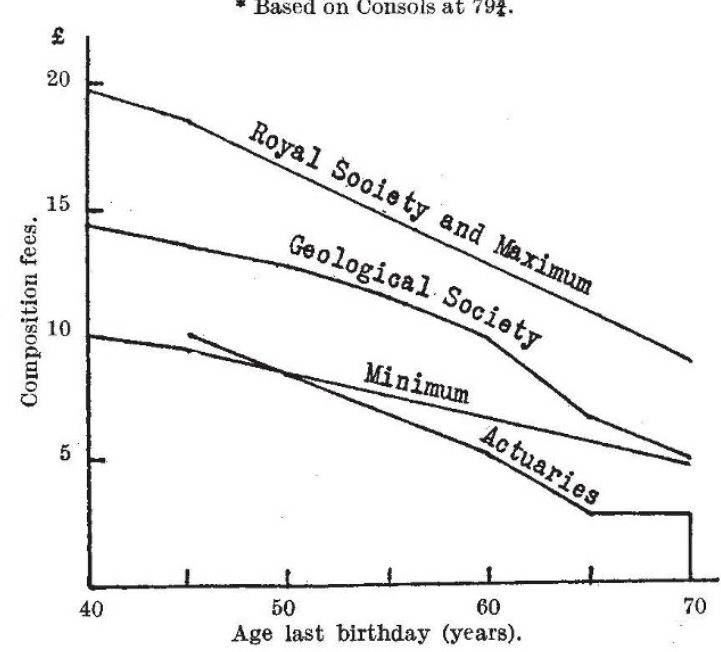

Any society which wishes to institute a scale of commutation fees should, I think, take into account the normal rate of withdrawal from its ranks. The suggested maximum scale, which assumes that withdrawals are impossible, will rarely, if ever, be applicable, and in general some percentage of the maximum should be used. Where withdrawals are rare, the percentage should be nearly 100 per cent, but where withdrawals are more frequent, as in societies the members of which are loosely held together only by a common interest in some field of activity, a lower percentage should be used. It is suggested 50 per cent of the maximum should be regarded as the minimum. Women should pay slightly higher commutation fees, but most societies will ignore this. In selecting a scale, simplicity is more important than adherence to exact actuarial values; in most cases either a single arithmetical progression or possibly two, as used by the Institute of Actuaries, will suffice. Thus the minimum commutation scale for a society with an annual subscription of 5 guineas might be 70 guineas at age twenty-five and decrease by one guinea for each additional year of age to a minimum of 20 guineas at age seventy-five.

What should be done with such commutation fees ? Most societies invest the whole of them and transfer to ordinary income only the interest earned; they thus build up useful hidden reserves in their accounts. Some further transfer to ordinary income is, however, reasonable and, in the absence of periodical actuarial investigation, it will in the long run be found satisfactory to transfer to ordinary income, in addition to the interest earned on the commutation fee fund, some small portion of each commutation fee received. This may be, say, one sixth, or alternatively the amount of one annual subscription. Only the balance of each commutation fee would then be invested. London, W.4. Aug. 4.

\section{Mr. W. L. Sclater}

Mavy years after his friends-Dr. A. C. Stark, the brothers H. F. and W. Francis and F. C. Selonshad lost their lives by enemy action, W. L. Sclater also fell a victim to enemy action ${ }^{1}$. Sclater was director of the South African Museum from 1896 to 1906 . He was appointed director when the new building (the present one) had just been completed, and his was the task of planning the arrangement of the exhibits. In the main his original plan persists, though with the logical alterations and extensions made possible by the addition of a new wing in recent years.

The late Dr. Peringuey was already on the Museum staff as entomologist. Sclater proceeded to assemble, as members of the staff or as honorary curators, a body of scientific workers to undertake research on the Museum collections : the late Dr. W. F. Purcell for invertebrates, the late Dr. Gilchrist for marine biology, the late Dr. Corstorphine for geology, and afterwards Dr. Rogers (happily still with us), and the late Dr. Pearson for botany; he himself took charge of the vertebrates. The acquisition of specimens was extended and accelerated by regular museum correspondents in all parts of the country, and the collections grew at a pace which has scarcely been exceeded in recent years, except in the various groups of invertebrates, even with the Museum's increased staff and facilities for field work.

To him was due the appointment of a promising young taxidermist, Mr. J. Drury of Perth, whose talents reached full fruition only after Sclater had resigned the directorship, and resulted in the unique series of casts of living Bushmen.

South African Museum, K. H. BARNARD. Cape Town.

${ }^{1}$ Nature, 154, 204 (1944). 